\title{
Sumatra's Orang-utans
}

\section{Markus Borner}

In the course of his WWF survey for rhinos in Sumatra, the author also made a study of orang-utans. He came to the conclusion that the total number in Sumatra is not more than $3500-4500$, despite higher figures that have been circulated, and that probably half of these - the animals living in forests outside the nature reserves - are severely threatened. Not only are they hunted and poached, but their habitat is being rapidly destroyed by big timber companies with concessions for clear-felling - $15 \frac{1}{2}$ million cubic metres of timber were exported in 1973.

In the first half of this century, the orang-utan Pongo pygmaeus was under strong hunting pressure in Sumatra and Borneo due to increasing demands from zoos, research centres and private animal collectors. Although legally protected in Indonesia and Malaysia, animals were freely available on the market, and few people cared about legal captures or export licences.

Barbara Harrisson, in 1961, was one of the first to call world attention to the orang-utan's precarious situation. In 1966, through the initiative of IUCN, the American Association of Zoological Parks and Aquariums (AAZPA) and the International Union of Directors of Zoological Gardens (IUDZG) banned the purchase of undocumented orang-utans, and import and export controls were established in several countries. These measures reduced the hunting pressure, but poaching still goes on.

Some short-term studies have been made on the orang-utan's status in Sumatra $(1,3,4,5,7)$. For the present study, the northern half of Sumatra was surveyed with special attention to the unexplored centres of the Gunung Leuser and Langkat reserves.

\section{Distribution}

Earlier surveys suggested that the southern boundaries of the orang-utan's range in Sumatra must be somewhere along the line of the strip of cultivated land north of Lake Toba, that separates the primary forests of north and central Sumatra. However, there were persistent rumours that they occurred south of this strip, and I was able to check some of these.

In Rumbai, a small town in Riau, central Sumatra, the owner of a confiscated orang-utan about eight years old believed that it had been caught in the lowlands of Riau; in fact it was confirmed that the dealer who had supplied it had bought if off a ship coming from Aceh. At several places in central Sumatra villagers claimed that orang-utans occurred in their area, but further questioning always showed that they did not mean Pongo pygmaeus, but the orang hutan (Malay: man of the forest), meaning either the ghost of the forest or the Kubu, a primitive hunting tribe living in the forest. 'Mawas', the local name for orang-utans (in Aceh and North Sumatra provinces) was not known to them. At some other places, like Torgamba in the southern part of North Sumatra province, timber workers and villagers said that orang-utans occurred, but surveys in the forests showed no signs of them. Often, such answers are only given to please the foreigner.

In December 1973, a male 10-12-year-old orang-utan was shot just outside 


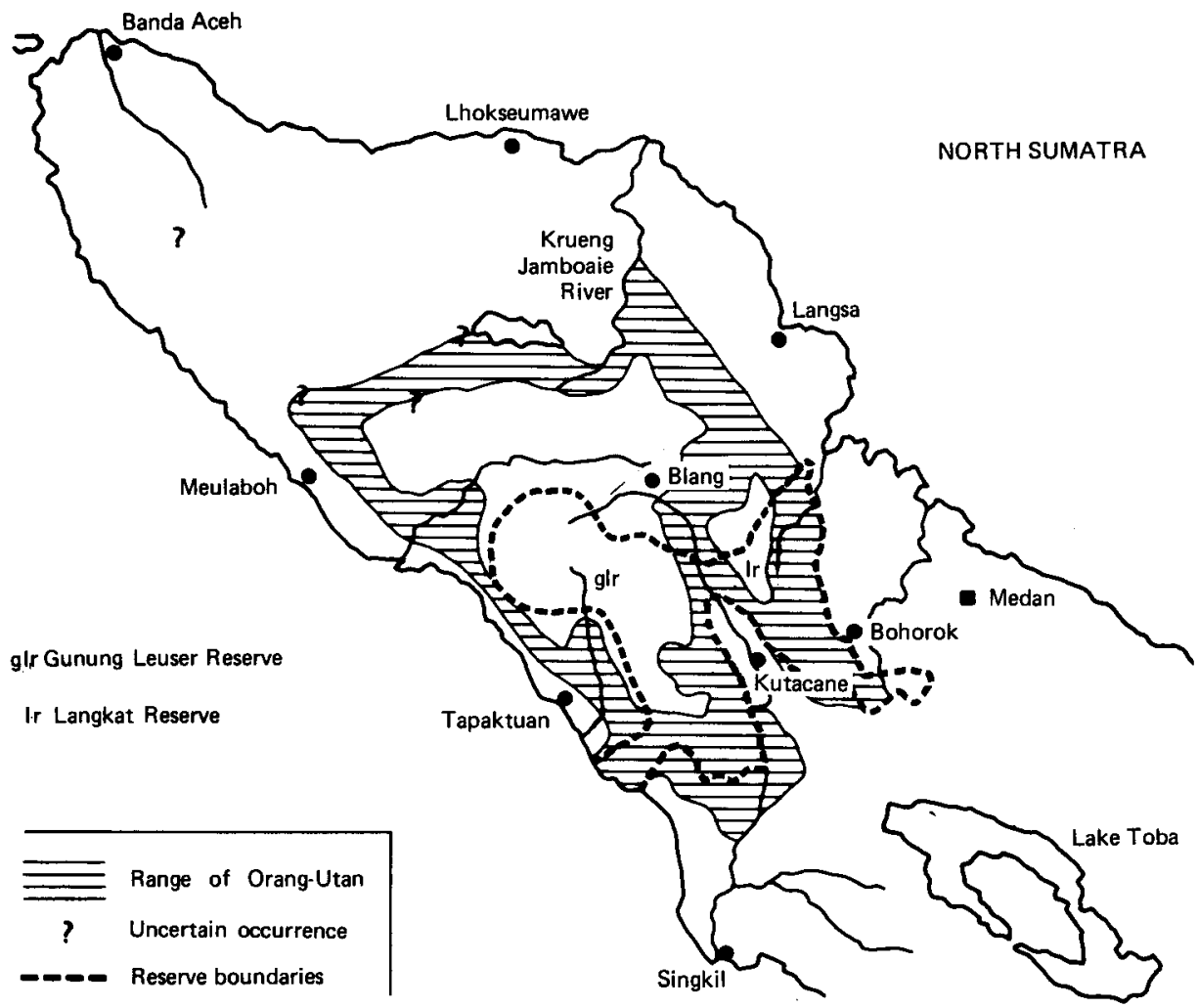

Rimba Panti, a small nature reserve about $80 \mathrm{~km}$ north of Bukittinggi in West Sumatra, and only one kilometre from the main road. Investigations showed that the local villagers had never seen an orang-utan before, and had thought it was a giant pig-tailed macaque. This orang-utan was running on the ground despite the fact that the path, which was steep and slippery, was edged with dense forest. Probably it had been kept in captivity by people who, when it grew too large, released it near the reserve, the only point on the MedanPadang road where there is undisturbed primary forest. After this incident some villagers claimed that shortly before they had seen two other small black 'orang-utans' walking on the ground. But not a single orang-utan nest could be found in the area, and this forest has no connection with any known orang-utan area; the dead male was the only 'evidence' whatsoever of orangutans in central Sumatra.

The southern boundaries of the orang-utan range, as postulated by Carpenter and Kurt, could be partly confirmed. In the south-east it more or less follows the Langkat Reserve boundaries, as all areas outside the reserve are now under cultivation. In the south-west the area is not yet densely populated, therefore primary forest and orang-utans are found south and west of the Gunung Leuser reserve. But intensive cultivation in the Alas valley is pushing back the southern boundary.

As central Aceh is mainly high mountains, orang-utans are concentrated in the lowland forests on the east and west coasts, where there are the greatest human population pressures; the primary rain forest, and with it the orang- 


\section{Table 1: Estimate of total number of orang-utans in Sumatra}

$\begin{array}{clc}\begin{array}{c}\text { Inside a reserve } \\ \text { below } 800 \mathrm{~m} . \\ \text { above } 800 \mathrm{~m} .\end{array} & \begin{array}{l}\text { Orang-utan range } \\ \text { about } 1500 \mathrm{~km}^{2}\end{array} & \begin{array}{c}\text { Number } \\ \text { about } 2000 \mathrm{~km}^{2}\end{array} \\ \begin{array}{c}\text { Outside a reserve } \\ \text { below } 800 \mathrm{~m} . \\ \text { above } 800 \mathrm{~m} .\end{array} & \begin{array}{l}1000-2000 \mathrm{~km}^{2} \\ \text { about } 2000 \mathrm{~km}^{2}\end{array} & \begin{array}{c}1000-2000 \\ 500\end{array} \\ { } &{\text { Total } 3500-4500}\end{array}$

utan habitat, is rapidly vanishing. On the east coast, orang-utans occur up to the Krueng Jamboaie river, which flows into the sea east of Lhok Seumawe. On the west coast, orang-utans are quite abundant up to Blang Pidi/Meulaboh further north their occurrence is uncertain. According to Mr Poniran, Head of the Aceh Nature Conservation Department, they might be found up to Lamno, some $100 \mathrm{~km}$. south of Banda Aceh.

It is now known that orang-utans occur at higher altitudes than had been thought. Carpenter estimated their highest altitude at about $1500 \mathrm{~m}$., but during this survey I saw one animal at $1700 \mathrm{~m}$. and nests up to $1860 \mathrm{~m}$. Population density in these higher altitudes, however, seems to be very low. Although about two-thirds of the $1500 \mathrm{~km}$. covered by foot in the forest were above $800 \mathrm{~m}$., only seven animals were seen, whereas below $800 \mathrm{~m}$. 26 animals were seen. In fact most of the Langkat reserve is suitable for orang-utans with the exception of the high mountain ridge in the north-west.

In the Gunung Leuser reserve, the orang-utan was formerly thought to be restricted to small peripheral areas, but the survey showed that it also occurs near the centre of the reserve, although at a low density, the altitude being $1000-1300 \mathrm{~m}$. and more. At least half the reserve, where the mountains rise to $3400 \mathrm{~m}$., is not suitable for orang-utans.

\section{Estimate of Numbers}

It was not possible to work out proper density figures for different areas, as the search was primarily for rhinoceros and therefore track-orientated; nests and animals in the trees may have escaped notice, and most of the areas were visited only once. In order to get an estimate of total numbers the following assumptions were made:

1. For orang-utan areas below $800 \mathrm{~m}$. John MacKinnon's density figures were adopted. (MacKinnon studied the orang-utan at three different places in Sumatra: West Langkat 1-2 orangs $/ \mathrm{km}^{2}$; Ranun South, ca 1.0 orangs $/ \mathrm{km} .{ }^{2}$, Ranun North less than 1 orang $/ \mathrm{km}^{2}{ }^{2}$ ) H.D. Rijksen, in this study area in the Alas valley, found a density several times higher (pers. comm.), but that area is extremely rich in fruit trees and these data are not considered representative; moreover the wild animals might be attracted by the semi-wild population and also by the additional food they could get at the rehabilitation station.

2. For orang-utan areas above $800 \mathrm{~m}$. a rough estimate was based on the author's own data of about 0.25 orangs $/ \mathrm{km}^{2}$. The formula, summarised in Table 1, was therefore: orang area below $800 \mathrm{~m} . \times 1.0$, orang $/ \mathrm{km} .{ }^{2}$ plus, orang area above $800 \mathrm{~m} \times 0.25$ orang $/ \mathrm{km}^{2}{ }^{2}$.

This estimated total of 4500 orang-utans in Sumatra must be considered a 
maximum, as the orang-utan's range outside the reserves is shrinking rapidly. Timber exports from Indonesia have increased enormously, from a bare 0.6 million cu.m, in 1967 to 15.5 million cu.m in 1973 (8). In Aceh alone three licensed timber concessions work beside several smaller companies. The three main companies have a concession of $1950 \mathrm{~km} .^{2}$ and export about 170,000 cu.m. of wood pear year (9), mainly from the lowlands of the east and west coast. These are the main orang-utan habitat outside the reserves, and it is therefore vanishing rapidly. Moreover, hunting and capturing are still serious threats. Orang-utans are still smuggled out of the country, despite the agreement of zoos not to import unlicensed orang-utans and despite strict export laws from Indonesia. Mostly they are young ones, obtained by shooting the mother; they are sold to expatriates or Indonesian officials for up to US $\$ 300$.

\section{Conservation Work}

The Indonesia Nature Conservation Department (Dinas Perlindungan dan Pengawetan Alam) does its best to confiscate these illegally held orang-utans. Confiscated animals are taken to a rehabilitation station, where they are gradually introduced to living in the forest again. Since 1972 almost 80 confiscated orang-utans have been taken to the stations in the Gunung Leuser reserve, near Ketambe river, and in the Langkat reserve, at Bohorok river (6). These two stations also play an important role in explaining and demonstrating the need for nature conservation and for nature reserves. They are a great attraction for tourists, both Indonesian and foreign, and through them the idea of protecting the orang-utan can be disseminated.

\section{References}

1. CARPENTER C.R. 1938. A survey of wildlife conditions in Aceh, North Sumatra with special reference to the orang-utan. Mededelingen No. 12, Nederlandsche Commissie voor Internationale Natuurbescherming, Amsterdam.

2. HARRISSON, B. 1961. Orang-utan - what chances of survival? Sarawak Museum Journal N.S. $10(17-18):$ : 238-261.

3. KURT F. 1971. Final report to IUCN/SCC and WWF International of WWF Project 596: Leuser Reserve, Sumatra (unpubl.).

4. MACKINNON M.J.R. a. Orang-utans in Sumatra. Oryx 12,2:234.

b. 1974 The behaviour and ecology of wild orang-utans. Pongo pygmaeus. An. Behav., 22:3-74.

5. Mirton O. 1964. The orang-utan and rhinoceros in North Sumatra. Oryx 7(4): 177-184.

6. RIJKSEN, Herman, D. and Ans G. RIJKSEN-GRAATSMA. 1975. Orang-utan rescue work in North Sumatra. Oryx 13(1): 63-73.

7. SCHENKEL R. and L. 1969. Report on a WWF mission to the Gunung Leuser Reserve (unpubl.).

8. 1972 . Forestry in Indonesia. Directorate General of Forestry, Department of Agriculture, Indonesia.

9. - 1972. Hutan kita. Direktorat Jenderal Kehutanan. Department Pertanian, Jakarta.

\section{Tamaraw Increase}

The tamaraw in the Mt Iglit reserve in the Philippines, one of two reserves for the animal on Mindoro Island, are doing well, and numbers are up to 80, reports David Kuehn who has worked there. It was as a result of the visit by Charles Lindbergh and Tom Harrisson (to which the FPS contributed some support) that protection for the tamaraw was achieved and reserves established, and now calves born since that date are getting to breeding age, which should step up numbers. The difficulty then may be that there will be too many for the habitat and there will be need to establish other populations. 